\title{
STUDI PENINGKATAN MUTU MADRASAH TSANAWIYAH DI KOTA JAMBI
}

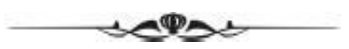 \\ Oleh: K.A. Rahman \\ Universitas Jambi
}

\begin{abstract}
Abstrak
Obyek penelitian adalah seluruh madrasah tsanawiyah di kota Jambi, negeri maupun swasta. Subyek penelitian kepala ma-drasah, guru dan komite madrasah. Bertujuan untuk menganalisis kebermaknaan kontribusi kepemimpinan kepala madrasah, iklim organisasi, dan partisipasi masyarakat terhadap mutu madrasah tsanawiyah, serta menemukan strategi peningkatan mutu madrasah. Metodologi penelitian dengan survei melalui pendekatan kuanti-tatif dan menggunakan teknik kuisioner. Ditemukan bahwa kepemimpinan kepala madrasah berkontribusi signifi kan terhadap mutu madrasah. Namun terungkap pimpinan madrasah belum maksimal mengkomunikasikan program madrasah pada masyarakat. Iklim organisasi berkontribusi signifi kan terhadap mutu madrasah. Namun temuan menunjukkan bahwa guru dan kepala sekolah kurang membaur satu sama lain. Partisipasi masyarakat berkontribusi signifi kan terhadap mutu madrasah. Namun temuan menunjukkan bahwa madrasah belum sepenuhya melibatkan pihak masyarakat. Mutu madrasah dikembangkan dengan memotivasi siswa agar sering tampil pada perlombaan, untuk melatih keterampilan berkomunikasi, serta meraih prestasi yang bisa meningkatkan rasa percaya diri.
\end{abstract}

Kata Kunci: Kepemimpinan, Iklim Organisasi, Partisipasi Masyarakat, Mutu Madrasah 


\section{A. Latar Belakang Masalah}

Kondisi Madrasah masih belum memenuhi harapan. Menurut catatan Kementerian Agama tahun 2009/2010, jumlah Madrasah Tsanawiyah (MTs) yang terakreditasi baru 76\% dari jumlah 14.022. Sebanyak 1.199 Madrasah berhasil terakreditasi A, atau baru 8,6\%. Madrasah yang beruntung mendapatkan akreditasi B berjumlah 5.757, sedangkan yang terakreditasi C berjumlah 3.698 Madrasah. Selain itu, masih ada 3.368 yang nasibnya belum jelas karena belum terakreditasi. Sebagaimana diketahui, akreditasi menjadi salah satu upaya untuk mengukur mutu atau tingkat kemajuan suatu sekolah yang dilakukan oleh badan akreditasi dengan mengacu pada delapan standar pendidikan. Akreditasi dilaksanakan berdasarkan Peraturan Menteri Pendidikan Nasional nomor 29 Tahun 2005 tentang Badan Akreditasi Nasional. Akreditasi terhadap sekolah dan Madrasah di-lakukan satu atap dalam satu wadah Badan Akreditasi Sekolah dan Madrasah (BAN S/M) di tingkat Provinsi dilakukan oleh BAP S/M.

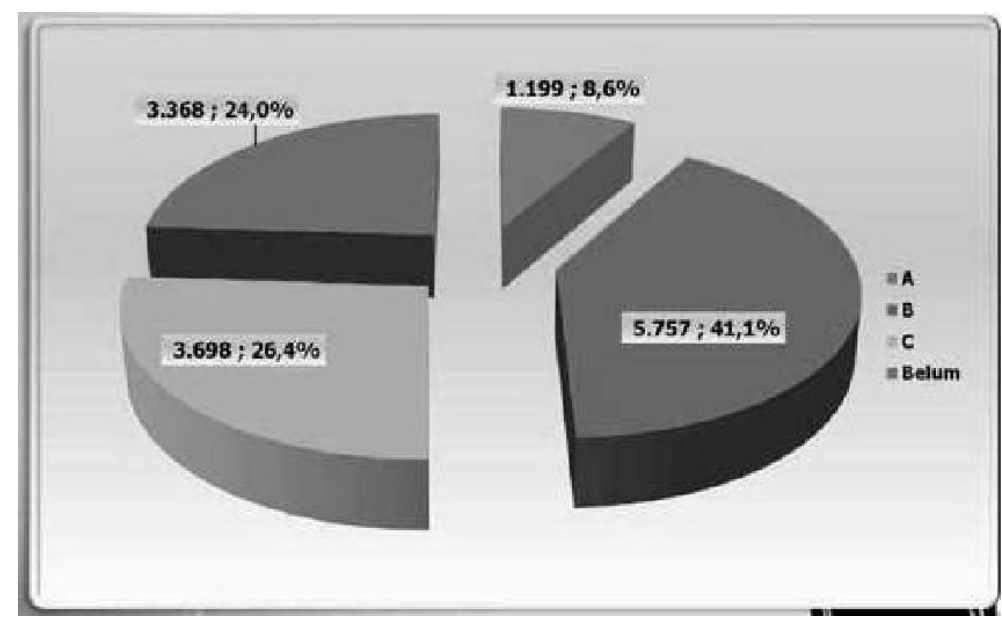

\section{Gambar 1}

Data Akreditasi Madrasah Tsanawiyah tahun 2009/2010

Sumber : Setditjen Pendidikan Islam, bagian perencanaan data, Kemenag.

Data dari Kementerian Agama Provinsi Jambi, menyebutkan bahwa Madrasah Tsanawiyah di kota Jambi, terdiri dari enam MTs 
Negeri dan dua puluh lima MTs swasta. Hanya MTs negeri yang telah tercukupi daya tampungnya, sementara yang swasta harus "pasrah" menerima siswa baru yang ternyata telah ikut tes masuk di sekolah lain namun dinyatakan tidak lulus. Sementara itu, dari segi akreditas, tidak ada satu pun sekolah tersebut yang memperoleh nilai akreditasi A. Hanya delapan MTs Negeri dan Swasta yang memperoleh nilai akreditasi B. Sisanya terakreditasi dengan nilai C. Bahkan masih terdapat lima MTs yang belum terakreditasi hingga tahun 2009 .

Madrasah masih menyimpan sejumlah persoalan yang patut menjadi perhatian. Pertama, partisipasi masyarakat terhadap Madrasah masih rendah. Kalau pun masuk Madrasah, itu dilakukan karena putra-putrinya tidak tertampung di sekolah. Kalau pun sudah masuk dan diterima sebagai siswa Madrasah, mereka sering mengabaikan biaya pendidikan bagi anak-anaknya. Ketika dilakukan survey ke Madrasah, banyak ditemukan siswa yang menunggak SPP karena belum dibayarkan oleh orang tua mereka. Rendahnya partisipasi masyarakat tersebut mungkin bisa jadi beralasan, karena sebagian besar wali murid Madrasah adalah mereka dari golongan ekonomi lemah. Persoalan kedua, adalah lemahnya manajemen dan leadership. Kondisi administrasi, kepemimpinan kepala sekolah, kinerja guru, staf dan seterusnya masih memprihatinkan. Persoalan lainnya adalah berkaitan dengan iklim Madrasah yang belum menunjukkan keterpaduan. Hubungan antar personal pun masih harus diperjuangkan agar lebih harmonis.

\section{B. Rumusan Masalah}

Rumusan masalah secara umum adalah: "Bagaimana kontribu-si kepemimpinan kepala Madrasah, iklim organisasi, dan partisipasi masyarakat terhadap mutu Madrasah Tsanawiyah di Jambi?”. Sedangkan secara rinci, rumusan masalah dinyatakan sebagai berikut :

1. Bagaimanakah deskripsi kepemimpinan kepala Madrasah, iklim organisasi, dan partisipasi masyarakat serta mutu Madrasah Tsanawiyah di Kota Jambi?

2. Bagaimana kontribusi kepemimpinan kepala Madrasah terhadap mutu Madrasah Tsanawiyah di kota Jambi?

3. Bagaimana kontribusi iklim organisasi terhadap mutu Madrasah 
Tsanawiyah di kota Jambi?

4. Bagaimana kontribusi partisipasi masyarakat terhadap mutu Ma-drasah Tsanawiyah di kota Jambi?

5. Bagaimana kontribusi kepemimpinan kepala Madrasah, iklim organisasi dan partisipasi masyarakat secara bersama-sama terhadap mutu Madrasah Tsanawiyah di kota Jambi?

\section{Signifi kansi / Manfaat Penelitian}

Hasil penelitian ini diharapkan dapat bermanfaat baik dan aspek teoritis maupun praktis. Secara teoritis, penelitian ini diharapkan dapat bermanfaat terutama dalam hal:

1. Memberikan kontribusi yang berarti bagi pengembangan bidang ilmu pendidikan, terutama dalam administrasi pendidikan, dan khususnya dalam bidang peningkatan mutu Madrasah.

2. Memberikan sumbangan rumusan konsep atau dasar kajian yang dapat digunakan sebagai rujukan untuk peningkatan mutu Madrasah.

3. Menawarkan suatu pola dalam upaya peningkatan mutu kepala Madrasah menuju ke arah peningkatan mutu Madrasah.

4. Mengajukan alternatif strategi peningkatan mutu Madrasah yang terkait dengan kepala Madrasah, iklim organisasi, dan partisipasi masyarakat.

5. Hasil temuan penelitian ini dapat berguna sebagai masukan dan landasan untuk melakukan penelitian serupa pada waktu yang akan datang.

Sedangkan secara praktis, diharapkan bermanfaat untuk:

1. Bahan informasi, atau sebagai bahan masukan dan evaluasi bagi para praktisi pendidikan, antara lain ketua yayasan penyelenggara pendidikan, kepala sekolah atau guru, khususnya yang terlibat pada Madrasah Tsanawiyah kota Jambi.

2. Bahan pertimbangan dan rekomendasi serta saran kepada pihak pimpinan Madrasah dalam mengelola lembaganya, terutama saat pengambilan keputusan yang terkait dengan kebijakan strategi peningkatan mutu Madrasah dalam mengelola lembaganya. 
3. Bahan masukan bagi orangtua siswa, mengingat tuntutan mutu terhadap Madrasah membutuhkan partisipasi masyarakat luas, termasuk orangtua siswa.

4. Bahan pertimbangan bagi Mapenda Kementerian Agama dalam menyusun perencanaan dan kebijakan peningkatan mutu Ma-drasah Tsanawiyah di Jambi.

Hasil penelitian ini juga dapat menjadi pertimbangan dan rekomendasi kebijakan bagi pemerintah daerah dalam upaya menemukan strategi pengembangan Madrasah dengan melihat unsur-unsur yang berkontribusi secara signifi kan terhadap mutu Madrasah.

\section{Kerangka Pemikiran}

Kerangka pikir berawal dari keadaan Madrasah Tsanawiyah yang masih belum mencapai mutu standar serta efektifi tas sebagaimana yang diharapkan. Belum tercapainya mutu tersebut kemungkinan dipengaruhi oleh faktor kepemimpinan Madrasah, iklim organisasi, dan partisipasi masyarakat yang kurang memberikan kontribusi sehingga berdampak pada efektivitas manajemen di Ma-drasah Tsanawiyah.

Pendidikan sesungguhnya dapat dipahami secara luas. Pengertian pendidikan secara luas adalah segala pengalaman belajar yang berlangsung dalam segala lingkungan dan sepanjang hidup. Pengertian ini menyiratkan bahwa pendidikan telah dimulai sejak manusia berada dalam kandungan. Masa pendidikan pada pengertian luas ini adalah berlangsung seumur hidup dalam setiap saat selama ada pengaruh lingkungan. Pendidikan terus berkembang mewujudkan peradaban, sejalan dengan kehidupan manusia itu sendiri.

Apapun bidang pendidikan yang diteliti, sasaran akhir yang diharapkan adalah terjadinya peningkatan mutu. Mutu merupakan derajat keunggulan sebuah produk atau pelayanan. Sebuah produk yang bersaing dengan produk lainnya atau suatu pelayanan jasa yang bersaing memiliki tingkat keunggulan relatif. Produk atau pelayanan jasa yang lebih unggul adalah produk atau pelayanan jasa yang bermutu. Mutu merupakan kesempatan ajang berkompetisi yang sangat 
berharga, karena itu munculnya kompetitor merupakan sebuah wahana untuk meningkatkan mutu produk layanan jasa. Dengan demikian, mewujudkan pendidikan dengan mengikuti standar mutu adalah penting, sebagai bagian dari produk layanan jasa. Manajemen sekolah yang efektif atau sekolah unggulan itulah yang menjadi kerangka utama pola pikir Madrasah yang bermutu. Untuk mencapai arah tersebut beberapa variabel yang dominan meliputi kepemimpinan Madrasah, iklim organisasi, dan partisipasi masyarakat, berikut dimensi-dimensi yang mengiringinya.

Mutu dalam konteks pendidikan Madrasah dapat diartikan dengan beberapa pengertian. The International Encyclopedia of Edu-cation, menyebutkan mutu pendidikan sebagai "educational quality is equated with school outcomes, various school "inputs" are examined to determine the effect on student achievement". Charles Hoy dalam bukunya Improving Quality in Education, merumuskan kualitas pendidikan adalah evaluasi dari proses mendidik yang meningkatkan kebutuhan untuk menca-pai dan mengembangkan bakat siswa dalam suatu proses, dan pada saat yang sama memenuhi standar akuntabilitas yang ditetapkan oleh klien yang membiayai proses atau output dari proses pendidikan. ${ }^{1}$

Menurut Hoy dan Miskel, sekolah bermutu adalah sekolah yang efektif, yang terdiri dari tatanan input, proses, dan output. ${ }^{2}$ Dengan demikian, Madrasah bermutu adalah Madrasah yang menerapkan rumusan sekolah efektif. Secara output, hasil yang peroleh dari Madrasah efektif adalah : Pertama, dari aspek siswa, lulusan yang dihasilkan adalah siswa yang memiliki prestasi akademik yang unggul, punya kreativitas, percaya diri, aspiratif, tidak ragu untuk mengemukakan pendapat, memiliki ekspektasi yang tinggi, selalu hadir dalam kegiatan, dan memiliki tingkat kelulusan yang tinggi, dan sebaliknya, angka putus sekolah tidak ada sama sekali atau nol persen.

Kedua, dari aspek guru, sekolah yang bermutu memperhatikan kepuasan kerja guru, angka absen nol persen, dan pergantian atau hlm. 10

${ }^{1}$ Hoy, Charles, at.all. Improving Quality in Education, (London : Falmer Press, 2000),

${ }^{2}$ Hoy, Wayne K., dan Cecil G. Miskel, Educational Administration ; Theory, Research, and Practice, (McGraw-Hill, 2008), hlm. 91. 
memberikan amanah kepada guru untuk tugas-tugas tertentu. Komariah dan Triatna, mengemukakan bahwa guru merupakan ujung tombak pendidikan. Keberadaan guru menjadi aspek penting bagi keberhasilan sekolah, terutama bagi guru yang melaksanakan fungsi mengajarnya dengan penuh makna (purposeful teaching). Maksudnya guru sangat kompeten di bidangnya bekerja secara professional dan menjadi seorang yang serba bisa dan memiliki harapan tinggi terhadap profesi dan siswanya (high expectation all round). Guru menjadi seorang komunikator yang menanamkan harapan kepada siswanya (comunicating expectation) dan guru adalah seorang seorang yang cerdas yang senantiasa bergelut dengan ilmu pengetahuan serta menyenan-gi tantangan intelektual. ${ }^{3}$

Ketiga, dari aspek pengelola (administrator), sekolah bermutu juga memperhatikan kepuasan kerja para staf, menyediakan anggaran yang seimbang, dan memiliki staf yang komitmen dan loyalitas kepada Madrasah.

Keempat, dari luar Madrasah, masyarakat memberikan citra yang positif terhadap sekolah atau Madrasah, hingga menjadikannya pilihan utama untuk mempercayakan pendidikan putra putri mereka.

Kepemimpinan Madrasah, yang dalam hal ini ada pada sosok kepala Madrasah, hendaknya memiliki karakteristik yang mampu menggerakkan pilar-pilar dan elemen dalam mewujudkan kemajuan Madrasah. Lipham, mengemukakan beberapa karakteristik yang harus dimiliki oleh kepala sekolah, antara lain : Ahli dalam konsep, piawai dalam menjalin hubungan kemanusiaan, dan pakar dalam bidang teknis. Ahli dalam konsep maksudnya dapat menuangkan konsep dengan jelas, dapat pula menjelaskannya sebagai sebuah informasi yang mudah dipahami, dan konsep tersebut menjadi alat yang dapat menggerakkan roda organisasi. Kepala sekolah memiliki latar balakang pendidikan di bidang administrasi pendidikan. Mampu memotivasi guru, misalnya meminta guru agar benar-benar memi-liki keahlian di bidangnya, sehingga dengan demikian kemampuan menuangkan konsep dapat ditingkatkan. Selanjutnya harus terus memperbarui pengetahuan konseptual dengan cara mempraktekkan

$\begin{array}{ccccr}{ }^{3} \text { Komariah, Aan, dan Cepi } & \text { Triatna, Visionary } & \text { Leadership ; Menuju Sekolah } \\ \text { Efektif, } & \text { (Jakarta } & : & \text { Bumi } & \text { Aksara, }\end{array}$ 
teori yang ada hubungan dengan keahlianya. misalnya melanjutkan studi, mengikuti seminar, pelatihan, dan menulis karya ilmiah. Ring-kasnya, kepala sekolah yang efektif memiliki kemampuan mengelola program instruksional ; membina guru dan staf; menjadi pengayom bagi siswa ; mengelola keuangan dan fasilitas sekolah, serta mampu menjalin komunikasi dengan masyarakat. ${ }^{4}$

Dimensi iklim organisasi menurut Hoy dan Miskel, menyatakan tergambar dalam enam pola perilaku, yakni :

1. Perilaku yang mendukung dari kepala sekolah (Supportive Principal Behavior). Gambaran sikap yang ditunjukkan antara lain sikap untuk terbuka terhadap guru, mendengarkan pendapat dari guru, dan mendengarkan saran-saran serta masukan dari mereka. Mendiskusikan persoalan sekolah secara rutin bersama mereka dan bersedia menerima kritik yang sifatnya membangun.

2. Perilaku memerintah secara langsung oleh kepala sekolah (Direc-tive Principal Behavior). Gambaran sikap yang ditunjukkan adalah sikap menuntut yang tinggi akan adanya kinerja guru secara maksimal, melakukan pengawasan secara rinci, kepala Madrasah mengawasi secara menyeluruh aktivitas guru hingga pada urusan yang sekecil-kecilnya dan sangat mendetil.

3. Perilaku kepala sekolah yang membatasi ruang gerak guru (Restrictive Principal Behavior). Sikap yang tergambar antara lain membebani guru dengan tugas-tugas tambahan tanpa diberikan fasilitas yang memadai. Guru juga diberikan beban untuk mengurusi permasalahan dengan komite Madrasah.

4. Perilaku rekanan (Collegial Teacher Behavior). Melalui sikap ini, kepala Madrasah melakukan komunikasi secara terbuka dan interaksi langsung dengan pihak sekolah. Guru dapat saling berdiskusi untuk meningkatkan kompetensi mereka. Kepala Madrasah juga dekat dengan guru, siswa, serta warga sekolah.

5. Perilaku keintiman antar guru (Intimate Teacher Behavior). Dengan perilaku ini terjadi hubungan keakraban yang kuat antar guru. Guru saling mendukung dalam organisasi dan jaringan yang terpadu, dan saling mengenal dengan baik satu sama lain. Guru

\footnotetext{
${ }^{4}$ Lipham, James M. and James A. Hoeh Jr, The Principalship ; Foundations and Functions, (New York: Harper \& Row Publisher, 1996).
} 
juga bersosialisasi dengan pihak lain di sekolah secara baik.

6. Perilaku melepaskan antar guru (Disengage Teacher Behavior). Sikap yang tergambar adalah acuh tak acuh dengan guru dan pihak lain. Bila terdapat perilaku yang menyimpang dibiarkan saja tanpa dikomunikasikan. Kepala sekolah tidak fokus pada kegiatan di Madrasah. Juga terjadi saling kritik antar guru hingga memunculkan kesan negatif. 5

Dimensi partisipasi masyarakat, berdasarkan pendapat John Dean, yang menyatakan ada lima dimensi, yaitu: representasi Madrasah ke dunia luar; dukungan pemerintah (stakeholder); keterlibatan orang tua; menjalin hubungan dengan pihak swasta; dan mendorong penggunaan lingkungan masyarakat untuk bahan pelajaran. ${ }^{6}$

Dalam kajian organisasi perilaku para anggota termasuk pimpinan. Interaksi dan karakteristik perilaku tersebut akan berdampak pula pada kondisi iklim organisasi. Dengan demikian seorang pemimpin harus memahami dan memiliki pendekatan yang tepat untuk menghadapi berbagai situasi. Iklim organisasi akan terbentuk atas kepemimpinan kepala sekolah yang menjadi penentu kebijakankebijakan sekolah, selain itu juga dapat dipengaruhi oleh nilai-nilai yang dimiliki oleh para personil Madrasah.

Mutu Madrasah dapat diwujudkan dengan kepemimpinan yang tepat untuk melaksanakan keseluruhan unsur determinan terhadap kualitas yang diharapkan. Mutu Madrasah juga dapat dilihat dari sejauh mana iklim organisasi memberikan kontribusi positif terhadap terwujudnya mutu Madrasah. Kemudian sejauh mana kepala Madrasah mampu mendorong para personil sekolah serta memupuk keterlibatan orang tua dan partisipasi masyarakat agar dapat memberikan kontribusi positif terhadap terwujudnya mutu pembelajaran di Madrasah Tsanawiyah di Jambi.

Kerangka pikir pada penelitian ini dapat digambarkan dengan bagan sebagai berikut:

\footnotetext{
${ }^{5}$ Lipham, James M. and James A. Hoeh Jr, The Principalship ; Foundations and Functions, (New York : Harper \& Row Publisher, 1996).

${ }^{6}$ Dean, Joan, Managing The Secondary School, (London : Routledge, 1993), hlm. 203
} 
K.A. Rahman

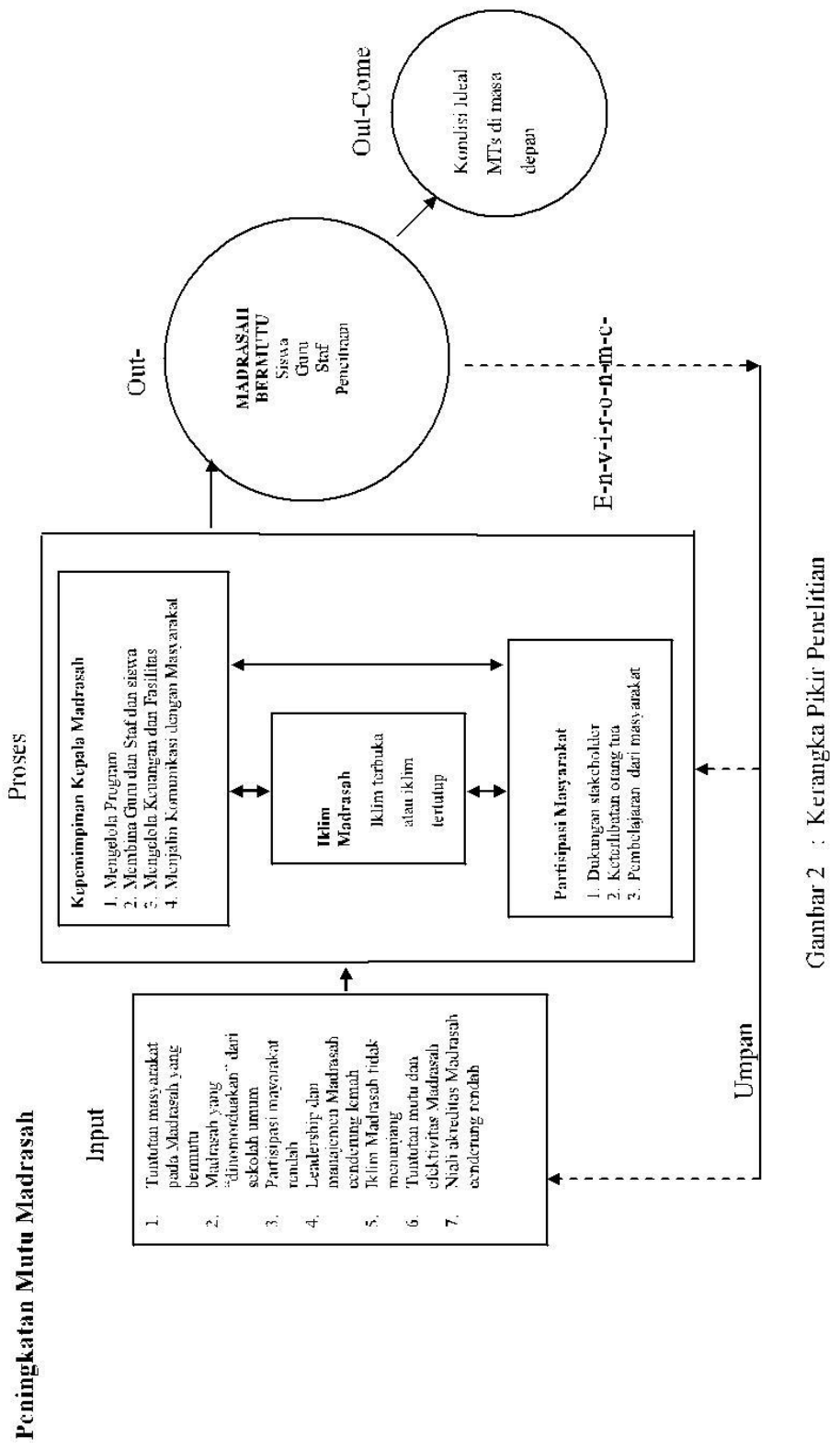




\section{E. Hipotesis Penelitian}

Hipotesis penelitian dengan demikian dapat diajukan sebagai berikut :

1. Kepemimpinan kepala Madrasah berkontribusi secara signifi kan terhadap mutu Madrasah

2. Iklim Madrasah berkontribusi secara signifi kan terhadap mutu Madrasah

3. Partisipasi masyarakat berkontribusi secara signifi kan terha-dap mutu Madrasah

Kepemimpinan, iklim organisasi, dan partisipasi masyarakat secara bersama-sama berkontribusi secara signifi kan terhadap mutu Madrasah.

\section{F. Metode Penelitian}

Penelitian ini menggunakan pendekatan kuantitatif dengan metode deskriptif survey. Penelitian metode survey terfokus pada pengungkapan hubungan antar variabel, yakni diarahkan untuk menyelidiki hubungan sebab akibat pada suatu variabel. Variabel sebab akibat tersebut adalah kepemimpinan kepala Madrasah (X1), iklim organisasi Madrasah (X2), partisipasi masyarakat (X3) dan mutu Madrasah Tsanawiyah (Y) di Jambi.

Penelitian ini dilakukan terhadap seluruh Madrasah Tsanawiyah di kota Jambi, baik negeri maupun swasta. Subyek penelitiannya adalah kepala Madrasah, guru kelas, dan anggota pengurus komite pada Madrasah Tsanawiyah. Sampel penelitian ini adalah Kepala Madrasah dan tiga orang guru kelas, masing-masing dari kelas satu, dua, dan tiga, ditambah satu orang pengurus/anggota komite Madrasah.

Sebelum kuisioner disebarkan pada sampel penelitian, terlebih dahulu dilakukan uji validitas dan reliabilitas instrumen penelitian. Pengujian validitas dan reliabilitas adalah proses menguji butirbutir pertanyaan yang ada dalam sebuah kuesioner, apakah isi dari butir-butir pertanyaan tersebut sudah valid dan reliabel. Jika sudah valid dan reliabel maka butir-butir tersebut sudah bisa mengukur faktornya. 


\section{G. Hasil Analisis Deskriptif}

Penelitian yang dilakukan pada 31 Madrasah Tsanawiyah neg-eri dan swasta di kota Jambi memperoleh data dari respoden yang terdiri dari kepala Madrasah, guru, dan komite Madrasah. Rentang waktu penelitian antara bulan Juni 2011 hingga bulan Januari 2012. Pengisian kuisioner oleh responden pada masing -masing Madrasah rata-rata berkisar satu minggu waktunya. Kepala Madrasah mengisi langsung berkas kuisioner yang diajukan peneliti. Sementara responden guru, diisi oleh masing-masing perwakilan guru yang menjadi wali kelas pada kelas satu, kelas dua dan kelas tiga. Responden komite Madrasah diisi oleh pengurus komite masing -masing Madrasah, rata-rata langsung oleh ketua komite. Sebagian diwakili oleh sekretaris komite, dan sebagian lagi oleh anggota komite Madrasah.

\section{Kepemimpinan Kepala Madrasah}

Rata-rata skor variabel kepemimpinan Madrasah pada tabel di atas, digambarkan dalam bentuk diagram sebagai berikut:

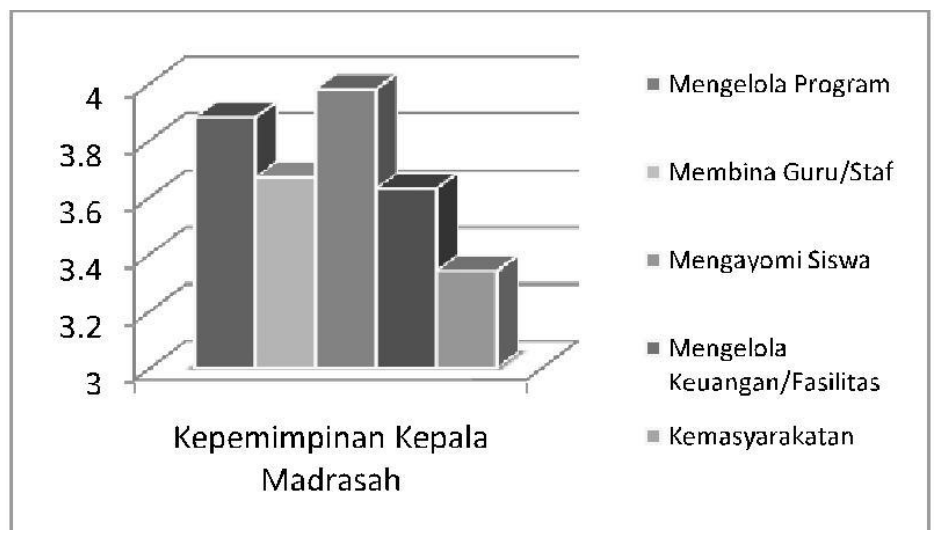

\section{Gambar 3 \\ Diagram Batang Kepemimpinan Kepala Madrasah}

Hasil tersebut tidak berbeda dengan hasil deskriptif berdasarkan responden yang memberikan tanggapan terhadap kepemimpinan kepala Madrasah, dengan gambaran berikut: 


\section{Kepemimpinan Kepala Madrasah}

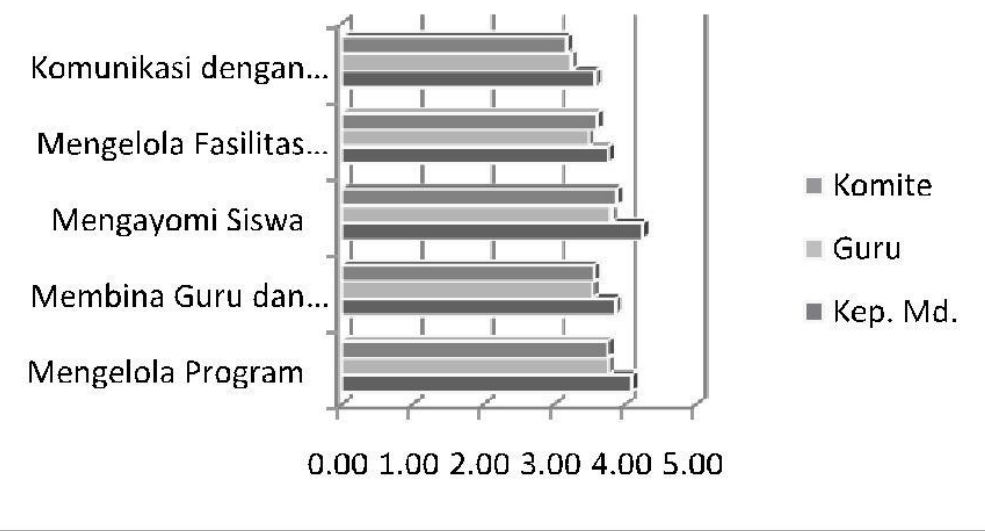

\section{Gambar 4}

Rata-rata Kepemimpinan Kepala Madrasah Berdasarkan Responden

\section{Iklim Organisasi Madrasah $\left(X_{2}\right)$}

Variabel Iklim Organisasi Madrasah ini secara lebih jelasnya dapat ditampilkan dalam bentuk diagram berikut ini:

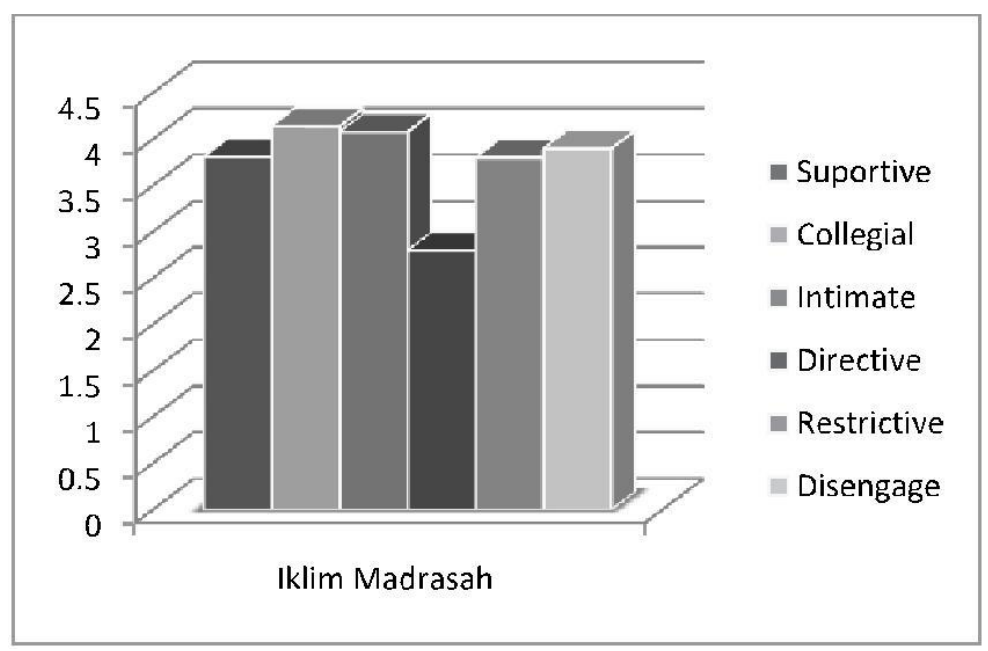

\section{Gambar 5}

Diagram Batang Iklim Organisasi Madrasah 
Sedangkan gambaran iklim Madrasah berdasarkan responden dilihat berikut ini:

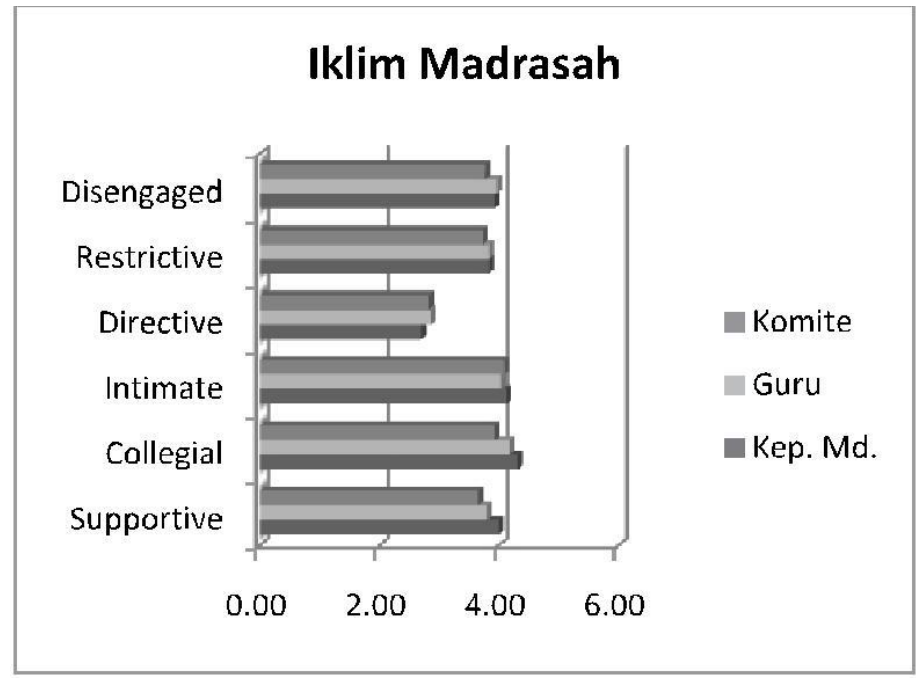

Gambar 6

\section{Diagram Rerata Iklim Organisasi Madrasah Versi Responden}

\section{Partisipasi Masyarakat $\left(X_{3}\right)$}

Keadaaan deskriptif partisipasi masyarakat dapat digambarkan melalui diagram sebagai berikut:

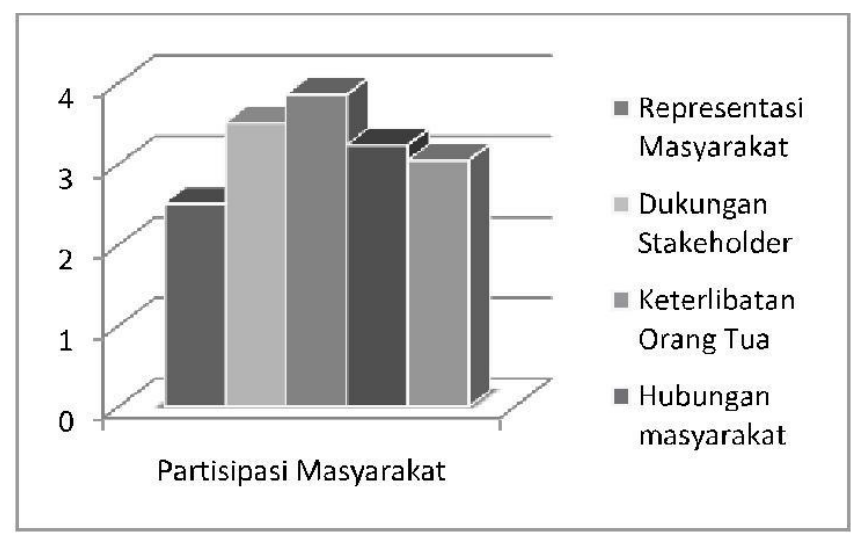

\section{Gambar 7}

Diagram Batang Partisipasi Masyarakat 
Adapun gambaran partisipasi masyarakat berdasarkan responden adalah sebagai berikut:

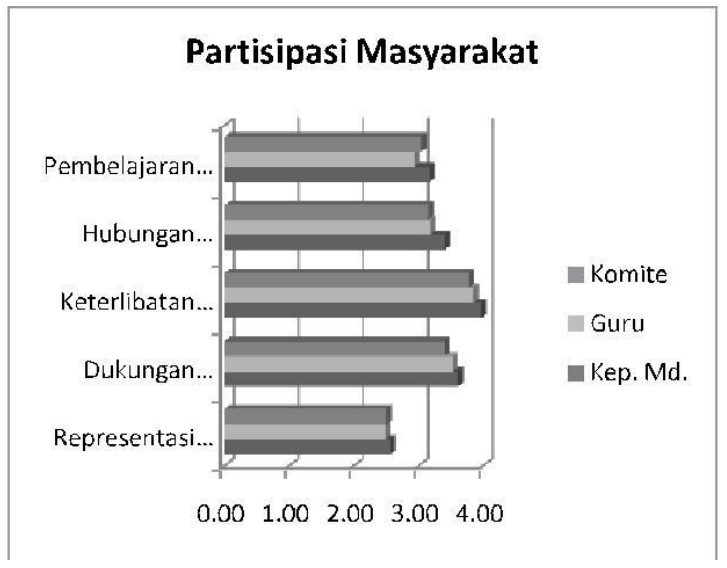

Gambar 8

Diagram Rerata Partisipasi Masyarakat Berdasarkan

Responden

\section{Mutu Madrasah (Y)}

Variabel Mutu Madrasah ini secara lebih jelasnya dapat ditampilkan dalam bentuk diagram berikut ini:

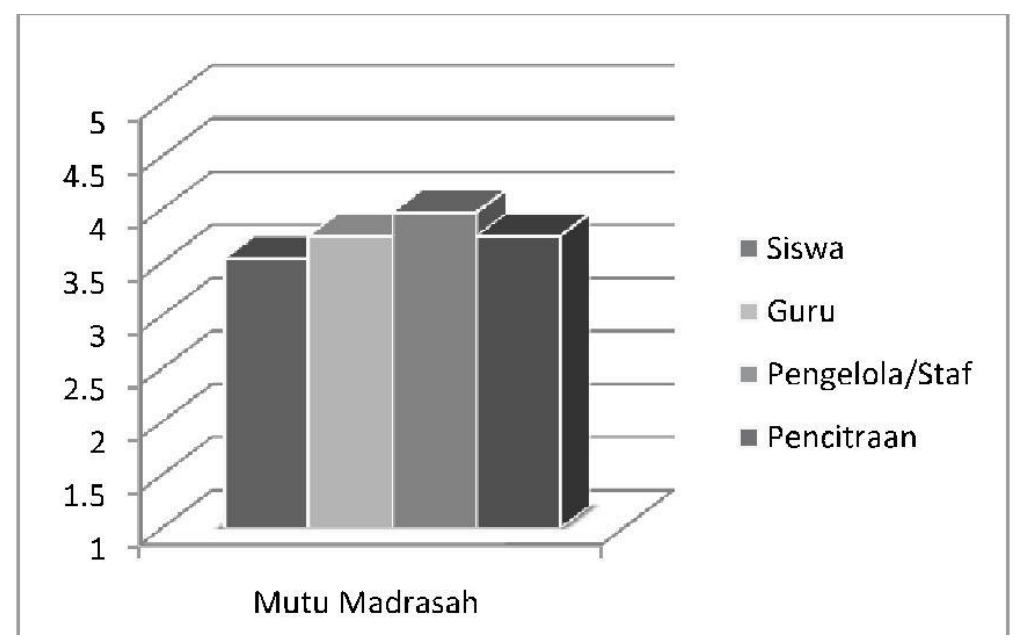

Gambar 9

Diagram Batang Mutu Madrasah 
Adapun deskripsi mutu Madrasah berdasarkan responden dapat dilihat berikut ini :

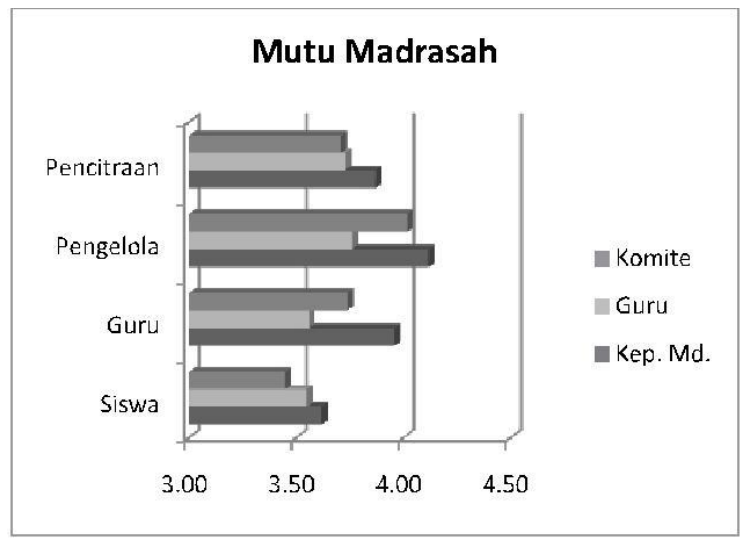

\section{Gambar 10}

\section{Diagram Rerata Mutu Madrasah Versi Responden}

Madrasah Tsanawiyah di Jambi terdiri dari Madrasah Negeri dan swasta. Untuk melihat deskripsi kepemimpinan, iklim organisasi, partisipasi masyarakat, dan mutu Madrasah Tsanawiyah Jambi dapat dilihat dari gambaran berikut:

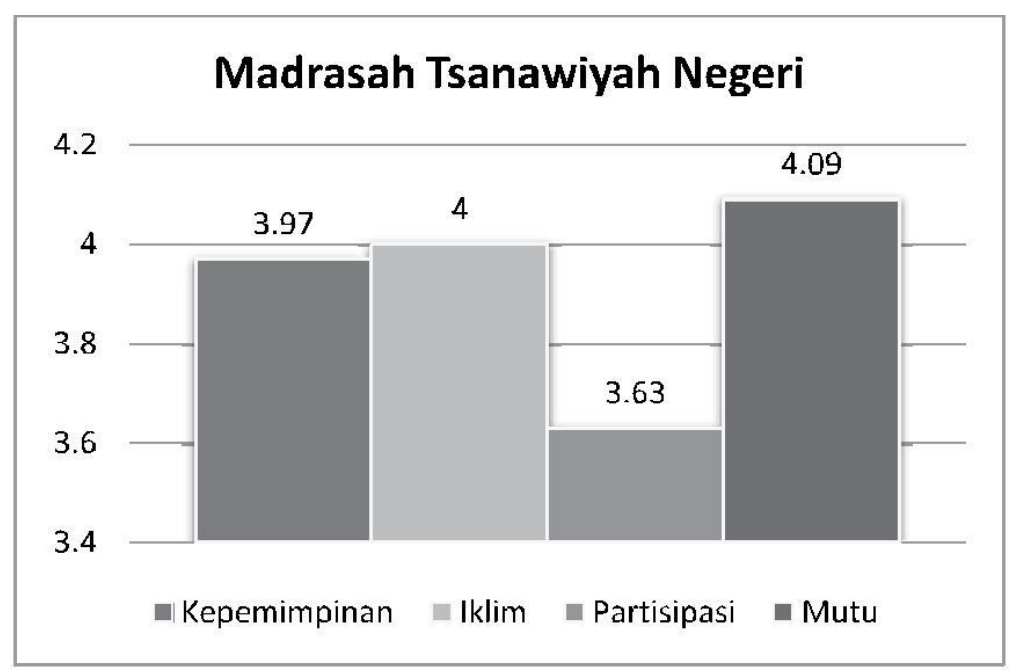




\section{Madrasah Tsanawiyah Swasta}
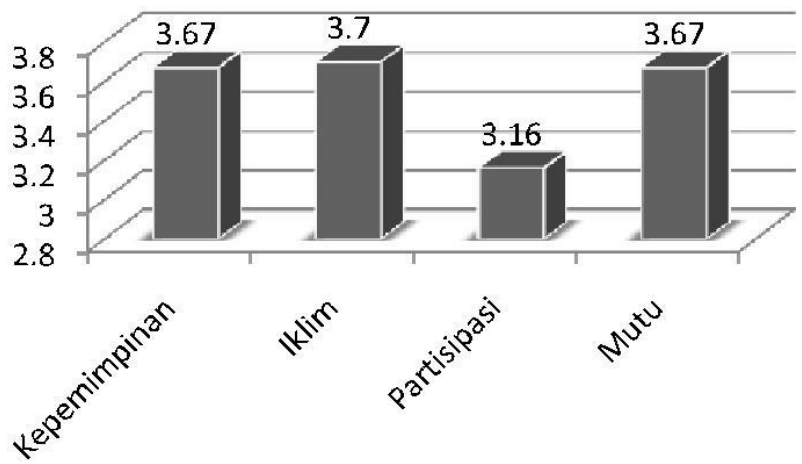

\section{Gambar 11}

Diagram Batang Rerata Mutu Madrasah Tsanawiyah Negeri dan Swasta

Kepemimpinan kepala Madrasah Tsanawiyah negeri lebih unggul daripada Madrasah Tsanawiyah swasta, dengan rata-rata 3,97 berbanding 3,67. Iklim organisasi negeri dan swasta adalah 4 berbanding 3,7. Partisipasi masyarakat pada Madrasah Tsanawiyah negeri juga unggul dari Madrasah swasta dengan perbandingan 3,63; 3,16; dan mutu Madrasah Tsanawiyah negeri lebih unggul daripada swasta dengan perbandingan 4,09: 3,67.

Secara umum deskripsi Madrasah Tsanawiyah negeri di kota Jambi lebih unggul daripada Madrasah swasta. Rata-rata skor deskripsi Madrasah Tsanawiyah negeri adalah 3,92 sedangkan skor rata-rata Madrasah Tsanawiyah swasta adalah 3,55.

\section{H. Hasil Pengujian Hipotesis}

Penelitian ini menjawab hipotesis yang diajukan, apakah diterima atau ditolak. Data yang diperoleh melalui penelitian ini dianalisis untuk menjelaskan kontribusi Kepemimpinan Kepala Madrasah ( $\left.\mathrm{X}_{1}\right)$, Iklim Organisasi Madrasah $\left(\mathrm{X}_{2}\right)$, Partisipasi Masyarakat(X3), dan Mutu Madrasah (Y). Hasil dikaji berdasarkan hasil pengujian hipotesis sebagai berikut: 


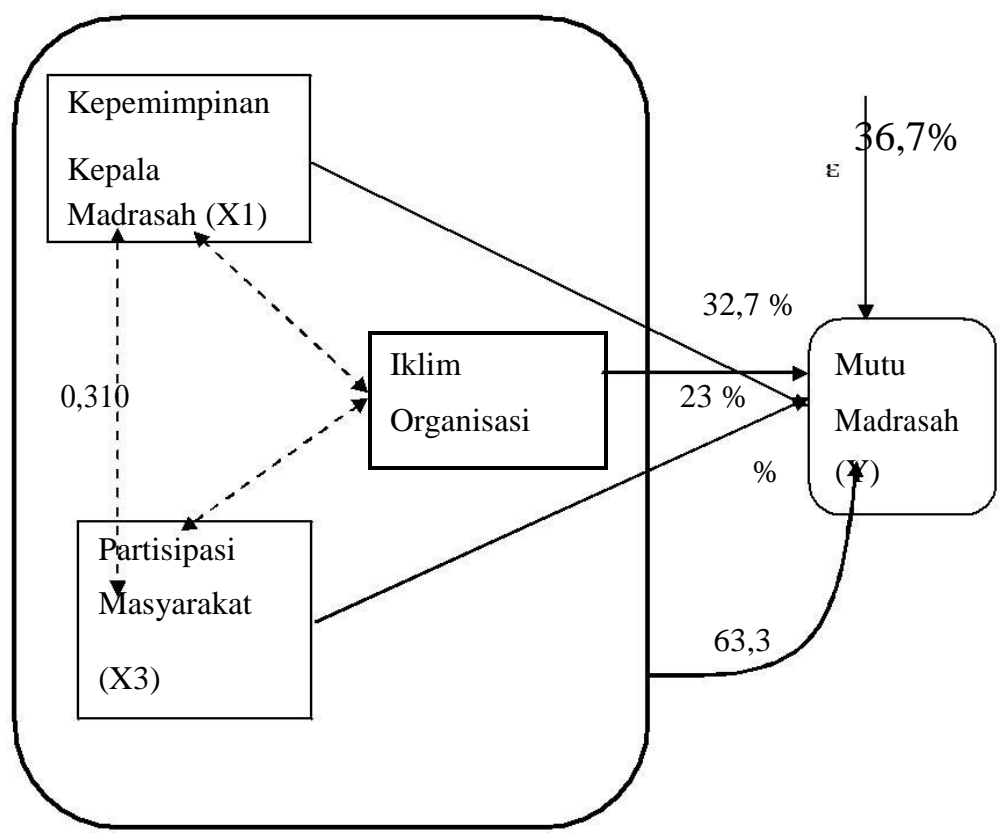

Gambar 12

Pola Kontribusi Variabel Penelitian

1. Hipotesis pertama "Kepemimpinan Kepala Madrasah berkontribusi secara signifikan terhadap Mutu Madrasah". Besarnya $0,572^{2}=0,327$ atau $32,7 \%$

2. Hipotesis kedua "Iklim Organisasi Madrasah berkontribusi secara signifikan terhadap Mutu Madrasah". kontribusi $0,480^{2}=$ $0,230=23 \%$

3. Hipotesis ketiga "Partisipasi Masyarakat berkontribusi secara signifikan terhadap Mutu Madrasah". kontribusi 0,6052 = 0,366 atau $36,6 \%$

4. Hipotesis keempat "Kepemimpinan kepala Madrasah, iklim organisasi dan partisipasi masyarakat secara simultan berkontribusi signifikan terhadap Mutu Madrasah”. Besarnya kontribusi $0,796^{2}=0,633$ atau $63,3 \%$ 


\section{Pembahasan}

\section{Kepemimpinan Kepala Madrasah}

Kontribusi Kepemimpinan Kepala Madrasah terhadap Mutu Madrasah sebesar 32,7 \% besarnya kontribusi signifikan terhadap Mutu Madrasah. Sedangkan korelasi antara kepemimpinan kepala Madrasah dengan Mutu Madrasah memberikan nilai koefisien sebesar 0,572 yang berarti hubungan cukup. Angka koefisien positif menunjukkan hubungan positif, yaitu jika kepemimpinan kepala Madrasah meningkat maka Mutu Madrasah juga akan meningkat.

Dimensi yang memberikan kontribusi paling rendah dalam kepemimpinan kepala Madrasah ini adalah dimensi kemampuan menjalin komunikasi dengan masyarakat. Indikator yang mendukung dimensi ini adalah: koordinasi kepala Madrasah dengan komite dalam menganalisis tujuan, sasaran dan prosedur Madrasah; melakukan penilaian sistematis persepsi masayarakat tentang harapan terhadap Madrasah; berpartisipasi secara luas dalam kegiatan kelompok masyarakat terutama organisasi masyarakat; menganalisis informasi yang dibutuhkan untuk publikasi Madrasah dan mempersiapkan dan mengadakan komunikasi berupa pertemuan bilamana diperlukan; mengemukakan program inovatif dan perencanaan untuk bekerjasama pada seluruh sumber daya yang ada di masyarakat; dan menjadikan pelaksanaan pendidikan yang digunakan masyarakat sebagai laboratorium pembelajaran. Rendahnya kontribusi dimensi kemampuan menjalin komunikasi dengan masyarakat ini menunjukkan bahwa pimpinan kurang mampu mengarahkan berbagai sumber daya yang dimiliki oleh Madrasah.

Oleh karena itu, dalam rangka meningkatkan mutu dan kualitas pendidikan Madrasah aspek kepemimpinan menjadi hal yang penting, yaitu bagaimana pemimpin Madrasah mempunyai stándar kompetensi dan kualifikasi yang telah ditentukan. Salah satu indikator kompetensi kepala Madrasah adalah menjadi narasumber atau pembicara terkait dengan kepemimpinan dan pengelolaan Madrasah di fórum-forum ilmiah. Menjadi pembicara di acara keagamaan seperti peringatan Maulid Nabi, Khotbah Jum'at dan sejenisnya adalah salah satu bentuk dan strategi berkomunikasi dan berinteraksi. Hal ini penting, sebab dengan interaksi-partisipasi dan komunikasi-aktif kepala Madrasah 
dapat meningkatkan kepercayaan dan tanggung-jawab warga terhadap Madrasah, serta sekaligus menjadi media pemasaran Madrasah yang efektif.

\section{Iklim Organisasi Madrasah}

Kontribusi Iklim Organisasi Madrasah terhadap Mutu Madrasah sebesar $23 \%$ besarnya kontribusi signifikan terhadap Mutu Madrasah. Sedangkan korelasi antara Iklim Organisasi Madrasah dengan Mutu Madrasah memberikan nilai koefisien sebesar 0,480 yang berarti hubungan cukup. Angka koefisien positif yang menunjukkan hubungan positif, yaitu jika Iklim Organisasi Madrasah meningkat maka mutu Madrasah juga akan meningkat.

Dimensi yang memberikan kontribusi paling rendah dalam Iklim Organisasi Madrasah adalah dimensi direktif. Indikator yang menunjukkan dimensi ini adalah; kepala sekolah menunjukkan sikap kaku pengawasan secara ketat atas segala aktivitas guru dan sekolah memperhatikan secara detil hingga sekecil-kecilnya. Keputusan ditetapkan sendiri oleh pihak pimpinan Madrasah tanpa musyawarah. Keputusan pimpinan Madrasah tidak bisa dibantah lagi dan harus dilaksanakan. Aturan yang ketat diberlakukan oleh pihak pimpinan Madrasah.Semua aktivitas guru diawasi pimpinan Madrasah Pelaksanaan tugas guru diperhatikan secara detail oleh pihak pimpinan Madrasah. Rendahnya kontribusi dimensi direktif ini menunjukkan bahwa seharusnya kepala Madrasah dapat memberikan pembinaan kepada guru, bukannya mengawasi secara ketat dan detail atas semua aktivitas guru.

Pendekatan yang ditawarkan oleh Glickman, bisa dijadikan alternatif untuk kepala Madrasah yang cenderung direktif. Ketika seorang pemimpin menggunakan perilaku non direktif untuk memahami titik pandang guru tapi kemudian berpartisipasi dalam diskusi dengan menghadirkannya sendiri ide-ide, pemecahan masalah dengan meminta semua pihak untuk mengusulkan kemungkinan tindakan, dan kemudian bernegosiasi untuk menemukan solusi umum dari tindakan memuaskan untuk guru dan pemimpin, maka kontrol atas keputusan tersebut dimiliki oleh semua. 
Hal ini dipandang sebagai pendekatan interpersonal yang kolaboratif. Ketika pemimpin instruksional mengarahkan guru suatu alternatif, guru dapat memilih. Setelah guru memilih, kepala Madrasah memberikan limit waktu yang diharapkan. Perilaku ini disebut pendekatan direktif kontrol interpersonal.

\section{Partisipasi Masyarakat}

Kontribusi Partisipasi Masyarakat terhadap Mutu Madrasah sebesar 33,6 \% besarnya kontribusi signifi kan terhadap Mutu Madrasah. Sedangkan korelasi antara Partisipasi Masyarakat dengan Mutu Madrasah memberikan nilai koefisien sebesar 0,605 yang berarti hubungan tinggi. Angka koefisien positif menunjukkan hubungan positif, yaitu jika partisipasi masyarakat Madrasah meningkat maka Mutu Madrasah juga akan meningkat. Dimensi yang memberikan kontribusi paling rendah dalam partisipasi masyarakat adalah dimensi representasi masyarakat. Indikator yang mewakili dimensi ini adalah; Anggota Madrasah menghadiri undangan pertemuan dari luar Madrasah dan anggota Madrasah menjadi pengurus organisasi di luar Madrasah. Rendahnya kontribusi dimensi partisipasi masyarakat ini menunjukkan bahwa masyarakat belum memberikan pengakuan terhadap anggota warga Madrasah untuk terlibat dalam kegiatan di tengah masyarakat. Guru atau kepala Madrasah juga belum aktif dalam suatu organisasi di tengah masyarakat.

Partisipasi masyarakat dapat diupayakan dengan lebih dahulu memberikan pelayanan terbaik dari pihak Madrasah kepada segenap pengguna Madrasah. Pelayanan merupakan hal yang sangat penting sebab Madrasah adalah lembaga yang kegiatannya melayani konsumen berupa murid, siswa, dan juga masyarakat umum yang dikenal dengan "stakeholder".Lembaga pendidikan pada hakekat-nya bertujuan memberi layanan. Pihak yang dilayani menginginkan kepuasan dari layanan tersebut, sebab mereka sudah membayarnya melalui berbagai hal seperti SPP, investasi bangunan, dana ujian, bayaran pajak, bantuan pemerintah kepada pihak sekolah untuk layanan pendidikan bagi warganya dan lain-lain. Jadi pihak konsumen berhak mendapatkan layanan yang memuaskan. 
Burns dan Gibbons, menawarkan agar orangtua siswa lebih banyak terlibat pada kegiatan Madrasah dengan memberikan intervensi. Pada tataran praktis, akan berdampak lebih baik bila Madrasah memberitahu orang tua dan mengusahakan dukungan mereka untuk memperoleh pemecahan masalah pada Madrasah. Orang tua harus diberikan akses untuk ikut serta memecahkan masalah pendidikan dengan memberikan data, waktu, peraturan, dan pengambilan kepu-tusan.

\section{Mutu Madrasah}

Kontribusi Kepemimpinan kepala Madrasah, iklim organisasi dan Partisipasi Masyarakat secara bersama-sama terhadap Mutu Madrasah sebesar 63,3\%. Sedangkan kontribusi oleh faktor-faktor selainnya terdapat $36,7 \%$. Ini menandakan bahwa kepemimpinan, iklim dan partisipasi merupakan faktor yang dominan berkontribusi pada mutu Madrasah karena memiliki porsi lebih dari $50 \%$.

Usaha peningkatan mutu Madrasah kaitannya dengan penciptaan partisipasi masyarakat maka perlu digiatkan upaya seperti fokus pada pelayanan, kedisiplinan, kemandirian, kecepatan dalam pengambilan keputusan, pengendalian strategik, dan teknologi unggul. Dengan demikian, budaya mutu akan menjadi kesadaran bersama dalam menciptakan proses pembelajaran yang efektif, efi sien dan berkualitas. Dampak dari terciptanya mutu Madrasah ini adalah kepuasan siswa.

Kualitas adalah upaya menghasilkan kerja yang baik sekaligus meningkatkan dan menjamin keberlangsungan kemajuannya. Taufiq, mengungkapkan bahwa dalam al-Qur'an terdapat prinsipprinsip umum mengenai kualitas. Misalnya tentang perbaikan terus menerus, Allah SWT berfirman:

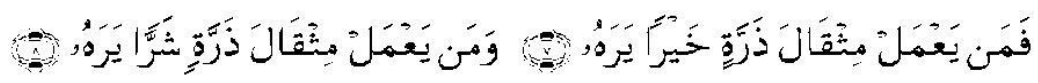

Barangsiapa yang mengerjakan kebaikan seberat dzarrahpun, niscaya Dia akan melihat (balasan)nya. dan Barangsiapa yang mengerjakan kejahatan sebesar dzarrahpun, niscaya Dia akan melihat (balasan)nya pula. (QS. az-Zalzalah/99: 7-8). 
Hasil uji hipótesis kontribusi 66,3 \% dari variabel Kepemimpinan Kepala Madrasah, Iklim Organisasi, dan partisipasi masyarakat secara simultan berkontribusi signifikan terhadap Mutu Madrasah ini memberikan gambaran yang menarik pada 31 Madrasah Tsanawiyah yang diteliti. Kesemuanya memberikan sumbangsih terhadap mutu Madrasah. Berdasarkan hasil uji hipótesis, ada empat unggulan dari tiap-tiap dimensi variabel yang diuraikan sebagai berikut: Pertama, dimensi mengayomi siswa mempunyai hubungan diantara variabel kepemimpinan kepala Madrasah sebesar 3,98. Kedua, dimensi collegial mempunyai hubungan tinggi diantara variabel Iklim Organisasi Madrasah sebesar 4,14. Ketiga, dimensi keterlibatan orang tua menempati hubungan yang tertinggi terhadap mutu Madrasah dalam dimensi partisipasi masyarakat dengan poin 3,86.

\section{Strategi Peningkatan Mutu Madrasah}

Program unggulan yang strategis untuk peningkatan mutu Madrasah di kota Jambi adalah peningkatan prestasi dan kemampuan siswa dalam bidang-bidang akademik, olah raga dan seni. Ditindaklanjuti dengan penyelenggaraan perlombaan untuk mengukur dan memberikan penghargaan kepada siswa yang berprestasi. Juga perlu adanya seminar yang melibatkan siswa, baik ditingkat internal Madrasah, maupun antar Madrasah. Hal ini diperlukan untuk melatih siswa dalam keberanian mengemukakan pendapat dan memupuk jiwa demokratis.

Peneliti menawarkan strategi sebagai berikut:

1. Implementasi pelatihan kepala Madrasah tidak saja mengenai kemampuan kompetensi profesional, tapi juga penguatan kompetensi sosial. Sehingga kepala Madrasah dapat melibatkan diri dalam kegiatan di tengah masyarakat sekitar Madrasah.

2. Implementasi kerja sama pihak Madrasah dengan masyarakat, misalnya dalam hal ketertiban lingkungan dan menguatkan peran organisasi kepemudaaan agar ikut melibatkan siswa Madrasah.

3. Implementasi sikap demokratis kepala Madrasah, melalui pelatihan dan pembiasaan, sehingga guru dapat bekerja secara maksimal dan nyaman tanpa ada kekuatiran dan intimidasi. 
4. Implementasi keikutsertaan masyarakat dalam merencanakan, merumuskan, melaksanakan dan mengevaluasi program Madrasah.

5. Implementasi perlombaan akademik yang diselenggarakan oleh pihak Madrasah bekerja sama dengan stakeholder atau pemerintah dan masyarakat.

Untuk mengukur bahwa strategi tersebut dapat diterapkan pada tingkat Madrasah Tsanawiyah, maka indikator yang dapat dike-mukakan antara lain:

1. Kepemimpinan kepala Madrasah dapat menjalankan fungsi profesionalnya dan demokratis dalam mengelola Madrasah, serta menjaga keakraban antar guru.

2. Iklim yang mendukung mutu Madrasah dapat terwujud, yakni terciptanya situasi dan kondisi dengan iklim terbuka, demokratis, dan kekeluargaan, dan terhindar dari iklim tertutup yang cenderung otoriter dan acuh tak acuh.

3. Partisipasi masyarakat telah terlibat aktif dalam kepentingan Madrasah. Stake holder siap membantu upaya peningkatan prestasi siswa dan mendukung program yang dijalankan Madrasah, serta ikut serta dalam mengawasi dan mengevaluasi.

4. Mutu Madrasah dapat terwujud dari berbagai segi: siswa yang meningkat prestasinya, berhasil mengikuti kejuaraan di luar Madrasah, dan siswa dapat memiliki kemampuan komunikasi secara baik, di sekolah maupun di tengah masyarakat.

5. Untuk jangka panjang, Madrasah Tsanawiyah dapat menjadi kompetitor sekolah-sekolah unggul dan Madrasah Tsanawiyah menjadi pilihan utama bagi siswa lulusan SD yang ingin melanjutkan jenjang pendidikan mereka. 

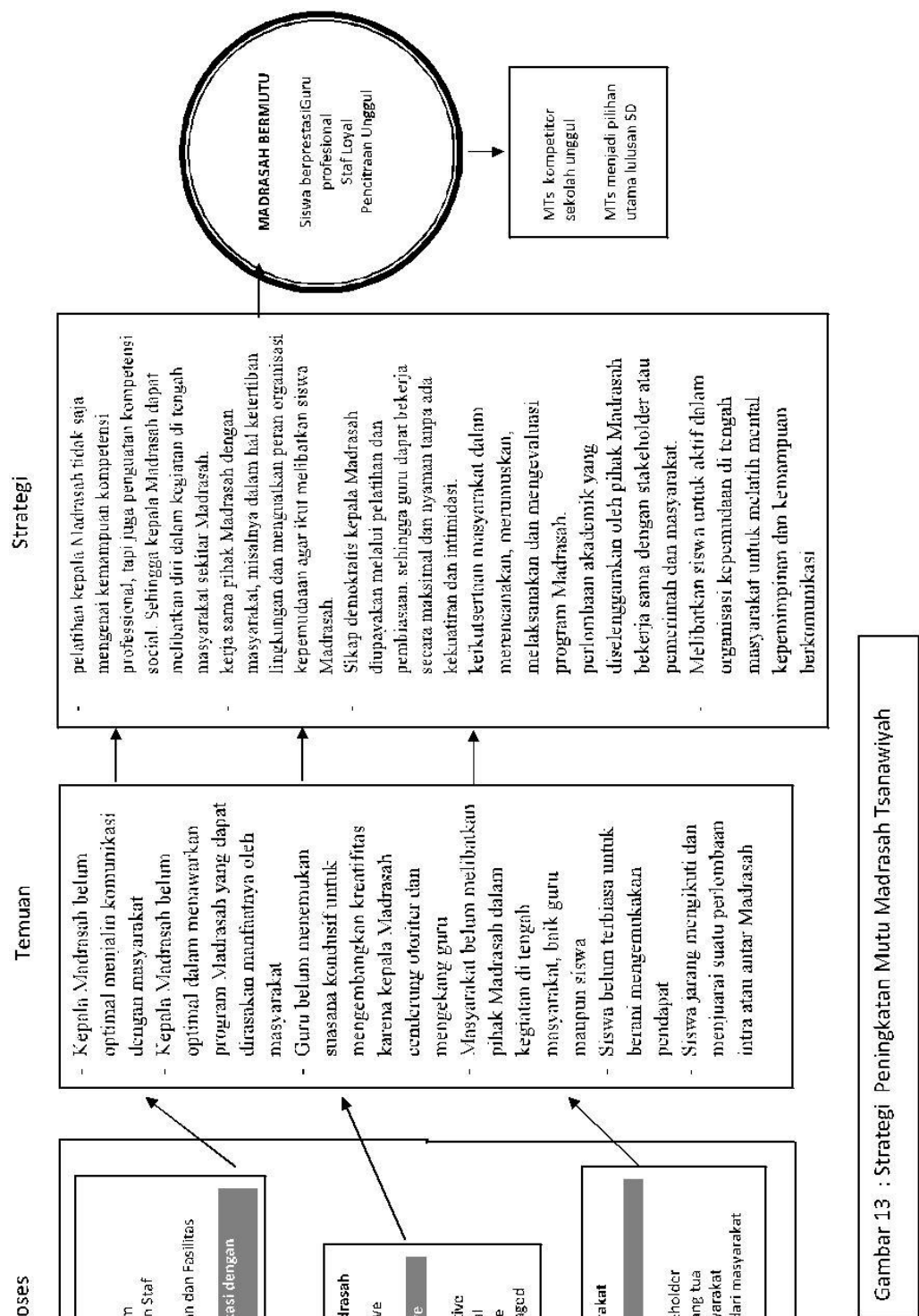


\section{J. Simpulan dan Saran}

\section{Simpulan}

a. Diperoleh gambaran deskriptif mengenai kepemimpi-nan kepala Madrasah di Madrasah Tsanawiyah negeri dan swasta di Kota Jambi relatif baik, iklim organisasi Madrasah baik, dan partisipasi masyarakat baik, serta mutu Madrasah relatif baik.

b. Hasil pengujian hipotesis membuktikan bahwa kepemimpinan kepala Madrasah berkontribusi secara signifikan terhadap Mutu Madrasah sebesar 32,7\%. Sedangkan koefisien korelasinya sebesar 0,572 yang berarti hubungan cukup. Angka koefisien positif menunjukkan hubungan positif.

c. Hasil pengujian hipotesis membuktikan bahwa iklim organisasi Madrasah berkontribusi secara signifikan terhadap mutu Madrasah sebesar 23 \%. Sedangkan koefisien korelasi sebesar 0,480 yang berarti hubungan cukup. Angka koefisien positif yang menunjukkan hubungan positif.

d. Hasil pengujian hipótesis membuktikan bahwa partisipasi masyarakat berpengaruh signifikan terhadap mutu pembelajaran sebesar 36,6 \%. Sedangkan koefisien korelasinya sebesar 0,605 yang berarti hubungan tinggi. Angka koefisien positif menunjukkan hubungan positif.

e. Hasil pengujian hipótesis membuktikan bahwa kepemimpinan kepala Madrasah, iklim organisasi Madrasah, dan partisipasi masyarakat secara simultan berkontribusi signifikan terhadap mutu pembelajaran sebesar $63,3 \%$ dan sisanya 36,7 $\%$ ditentukan oleh variabel lain.

f. Peningkatan mutu Madrasah Tsanawiyah dapat diupayakan dengan memperbaiki kinerja kepala Madrasah dalam menjalin komunikasi masyarakat, komunikasi internal dengan guru, dan memperkenalkan program Madrasah secara lebih intensif kepada masyarakat.

\section{Saran}

a. Temuan pada Madrasah Tsanawiyah negeri dan swasta di kota Jambi menunjukkan bahwa masih ada kelemahan pada 
kepala Madrasah yang belum menjalin komunikasi secara baik dengan masyarakat. Iklim antara guru dan kepala Madrasah yang masih kaku, dan partisipasi masyarakat yang belum melibatkan Madrasah dalam konteks kegiatan masyarakat. Hal ini perlu disikapi dengan strategi komunikasi dan harmonisasi antara pihak Madrasah dan masyarakat yang perlu dikembangkan, termasuk iklim internal antara kepala Madrasah dan guru. Masyarakat juga hendaknya diberi kesempatan untuk ikut terlibat dalam aktivitas Madrasah.

b. Kepemimpinan kepala Madrasah dapat menerapkan sikap kepemimpinan yang demokratis dan komunikatif sebagaimana tawaran Lipham; iklim yang dibangun adalah iklim yang terbuka sebagaimana ditawarkan Hoy dan Miskel; partisipasi masyarakat dapat dibangun dengan kolaboratif sebagamana tawaran Joan Dean, dan mutu Madrasah dapat ditingkatkan sehingga tercipta siswa yang berprestasi, guru dan staf yang loyal, dan mendapatkan pencitraan unggul di tengah masyarakat sebagaimana dibahas pada bab pembahasan.

c. Secara operasional, Madrasah dapat mengaktifkan kembali komite Madrasah dengan peran yang semaksimal mungkin; kepemimpinan kepala Madrasah dapat diasah pelatihan; guru sering terlibat di tengah masyarakat dengan memberikan ceramah atau terlibat dalam organisasi kemasyarakatan; dan untuk meningkatkan motivasi serta prestasi siswa dapat diadakan berbagai perlombaan, baik bidang seni maupun akademik, dengan memberikan penghargaan yang pantas kepada para juara. Karena itu perlu dikuatkan prinsip fastabiqul khoirot pada kepala Madrasah. Selain itu, partisipasi masyarakat yang sudah terbangun pada Madrasah hendaknya lebih ditingkatkan lagi, misalnya dengan menjadikan Madrasah sebagai tujuan utama bagi pendidikan anak. 


\section{DAFTAR PUSTAKA}

Akdon, 2007, Modul Aplikasi Statistika dalam Pendidikan, UPI: Program Magister Pendidikan Dasar.

Burns Matthew K. dan Kimberly Gibbons, 2008, Implementing response-to-intervention in primary and secondary schools, London: Routledge.

Creswell, John W., 2008, Educational Research. New Jersey: Pearson International Edition.

Dean, Joan, 1993, Managing The Secondary School, London: Routledge.

Glickman, Carl D., 2002, Leadership for Learning ; How to Help Teachers Succeed, Virginia: ASCD.

Hoy, Charles, at.all, 2000, Improving Quality in Education, London: Falmer Press.

Hoy, Wayne K., dan Cecil G. Miskel, 2008, Educational Administration; Theory, Research, and Practice. McGraw-Hill.

Komariah, Aan, dan Cepi Triatna, 2006, Visionary Leadership; Menuju Sekolah Efektif. Jakarta: Bumi Aksara.

Lipham, James M. and James A. Hoeh Jr., 1996, The Principalship ; Foundations and Functions. New York: Harper \& Row Publisher.

Lunenburg, Fred C dan Allan C. Ornstein, 2004, Educational Ad- 
ministration; Concepts and Practices. Thomson; Wodsworth.

Lunenburg, Fred C, dan Beverly Irby, 2006, The Principalship. Wadsworth Belmont USA.

Makmun, Abin Syamsudin, 2002, Lapangan Penelitian Pendidikan, Hand-Out Perkuliahan Metodologi Penelitian Pendidikan. UPI: Bandung

Meirawan, Danny, 2010, Kepemimpinan dan Manajemen Pendidikan Masa Depan, Bandung: IPB Press.

Sallis, Edward, 1993, Total Quality Management in Education, London: Kogan.

Sa’ud, Udin Saefudin, 2008, Inovasi Pendidikan, Bandung: Alfabeta.

Scheerens, Jap, 2003, Menjadikan Sekolah Efektif, Penerjemah Abas al-Jauhari, Jakarta: Logos, Dari teks asli Improving School Effectiveness. UNESCO tahun 2000.

Sugiyono, 2009, Metode Penelitian Pendidikan; Pendekatan Kuantitatif, Kualitatif, dan RひD. Bandung: Alfabeta. 
